\title{
INTEGRÁLT KOCKÁZATMENEDZSMENT A GYAKORLATBAN
}

\begin{abstract}
A kockázatmenedzsment-szakirodalomban sok módszer található, amely alkalmas lehet a kockázatok becslésére. Ám ezek közül több csak akkor használható, ha megfelelố mennyiségú és minốségú múltbeli adat áll rendelkezésre. Azonban a legtöbb kockázat értékeléséhez sokszor nem érhetố el ilyen naprakész adatbázis. Természetesen e kockázatok bekövetkezési valószínúségét és hatását is megbízható módon kell becsülni/értékelni. A kérdés csak az, hogy mi módon tegyük is ezt? A kérdés megválaszolására a szerzó kidolgozott egy módszert, amit máig már több mint ötven projekt esetében alkalmazott sikeresen. Az alkalmazások során szerzett tapasztalatokat felhasználva a módszert továbbfejlesztette. Ez a cikk a továbbfejlesztett módszer újdonságait foglalja össze. A cikkben található egy esettanulmány is annak szemléltetésére, hogyan lehet az általa kidolgozott megközelítéssel a kockázatokat felmérni és kezelni.
\end{abstract}

Kulcsszavak: integrált kockázatmenedzsment, kockázat-adatbázis, kvantitatív kockázatértékelés, kritikus kockázat, kockázatkezelés, kockázatkontrolling

A vállalati döntéshozók egyre inkább igénylik a stratégiai döntéstámogatásban rejlő bizonytalanságok modellezését, ily módon kapcsolatot teremtve a döntések és azok várható következményei között. A döntéstámogatás célja a kockázatok tudatos vállalása a profit maximalizálása érdekében. Ez az oka annak, hogy miért olyan aktuális téma jelenleg a vállalatok gyakorlatában a kockázatelemzés és a kockázatmenedzsment.

A szakirodalom bővelkedik a kockázatelemzés gyakorlatban történő megvalósítását lehetôvé tévô módszerekben és eszközökben. Ezeket áttanulmányozva azonban azt tapasztaltam, hogy ritkán mutatnak be szemléletes példákat alkalmazásuk megkönnyítésére. Felismerve mindezt, a módszer kifejlesztése során az elsődleges célom a vállalatok gyakorlatában könnyen alkalmazható, elméletileg jól megalapozott kockázatelemzési eljárás bevezetése. Ezt a módszert tárgyalom a cikk második fejezetében.

Mielőtt a részletekre rátérnék, elótte fontosnak tartom bemutatni, hogy különböző szerzók miként közelítik meg a kockázat fogalmát.

Bármely feladat megoldásának fontos lényegi sajátossága a bizonytalanságok jelenléte a tevékenységi folyamatban. A bizonytalanság bizonyos értelemben azonos az információhiánnyal, s a különféle eredetú bizonytalanságok sok esetben valamilyen kockázat for- májában jelennek meg. Ily módon kockázat nem létezik bizonytalanság nélkül. A bizonytalanság azt jelenti, hogy egy adott esemény bekövetkezését (idejét, helyét, módját) - vagy be nem következését - nem ismerjük pontosan. Ebben az értelemben a bizonytalanság ,semleges", hiszen nem tudjuk még, hogy az számunkra jó vagy rossz következményekkel jár-e. Ezzel szemben a kockázat többnyire a bizonytalanság számszerúsíthetô negatív vagy pozitív következményeit jelenti, miközben maga a bekövetkezés is bizonytalan, de annak valószínúsége leírható. Ebbő́l következôen a kockázat - a kockáztatás mértéke - mennyiségileg is mérhetô, ami így a negatív, illetve pozitív bekövetkezés valószínúségének és az azzal összefüggó veszteségnek, illetve nyereségnek a szorzata (Görög, 2008). Annak érdekében, hogy a kockázatokat értékelni lehessen, először meg kell határozni azokat a kockázati csoportokat/tényezőket, amelyek alanyai lesznek az értékelésnek.

Más megközelítések a „mellékhatásokra” koncentrálnak, az ô esetükben a kockázat fogalma általában egy bizonytalan eseményre utal, amelynek lehet negatív vagy pozitív kimenete is (Hillson, 2002). Van szerzô, aki szerint pedig egy adott kockázat szintjét úgy is meghatározhatjuk, mint az azzal kapcsolatos események valószínúsége és azok nagyságának szorzata (Hopkin, 2012). 
A cikk további részében a fent idézett kockázatfogalom-meghatározásokat veszem alapul az általam kifejlesztett kockázatértékelési eljárás egyes lépéseinek bemutatása során.

\section{A szerzố által fejlesztett kockázatértékelési módszer a vállalati döntések támogatásához}

A kockázatmenedzsment szakirodalmában számos olyan módszer található, ami alkalmas a kockázatértékelésre. A legtöbbjük azonban csak akkor használható, ha elegendô számú múltbeli adat áll rendelkezésre, amely jogossá tesz statisztikai módszerek alkalmazását a kockázatok értékelése során (pl. Jorion, 1997). Ha valaki például árfolyam- vagy kamatláb-kockázati kitettséget szeretne meghatározni, ehhez használhatók a statisztikai módszerek, mivel árfolyam vagy kamatláb alakulására napi rekordok állnak rendelkezésre. De mi a helyzet akkor, ha valaki annak a cégnek a stratégiai céljait befolyásoló kockázatok hatását szeretné értékelni, ahol dolgozik? Ebben az esetben ritkán létezik napi adatbázis a kockázatok értékeléséhez. Természetesen a kockázatok bekövetkezési valószínúségét és hatását minden esetben megbízható módszerrel kell értékelni/becsülni.

A kockázatmenedzsment szakirodalmában különbözô megközelítések vannak a kockázatértékelésre. Ezeket legalább két kategóriába sorolhatjuk: kvalitatív és kvantitatív módszerek csoportjába. A kvalitatív módszerek a gyakorlatban könnyen használhatók, de néha elófordul, hogy nem biztosítanak megbízható értékelést. A kvantitatív módszerek használata megbízható, viszont sok múltbeli adat szükséges hozzájuk. Így felmerül a kérdés: ha nincs elegendô múltbeli adat, miért nem állítjuk elő a kvantitatív értékeléshez szükséges input adatokat a résztvevôk többéves szakmai tapasztalatait felhasználva workshopok keretében (pl. Monte-Carlo-szimulációhoz), hogy megbízható kockázatértékelést végezhessünk.

A fenti kérdésre adott adekvát válaszként kidolgoztam egy módszert, amit PhD-értekezésemben korábban már publikáltam. Ezt a mai napig már több mint ötven, különböző feladat megoldásában alkalmaztam sikerrel. A különböző felhasználásokban szerzett tapasztalatokat alapul véve a módszert továbbfejlesztettem.

A cikk célja, hogy összefoglalja a továbbfejlesztett módszer újdonságait, és bemutassa, miként lehet ezt a gyakorlatban is alkalmazni.

A kockázatmenedzsmentet úgy írhatjuk le, mint a kockázatok azonosításának, elemzésének, értékelésének, kezelésének és kontrollingtevékenységének önmagába visszatérố ciklikus folyamatát (Cooper Chapmen, 1987; Chapmen - Ward, 2003; Projekt Management Istitute, 2008).

1. ábra

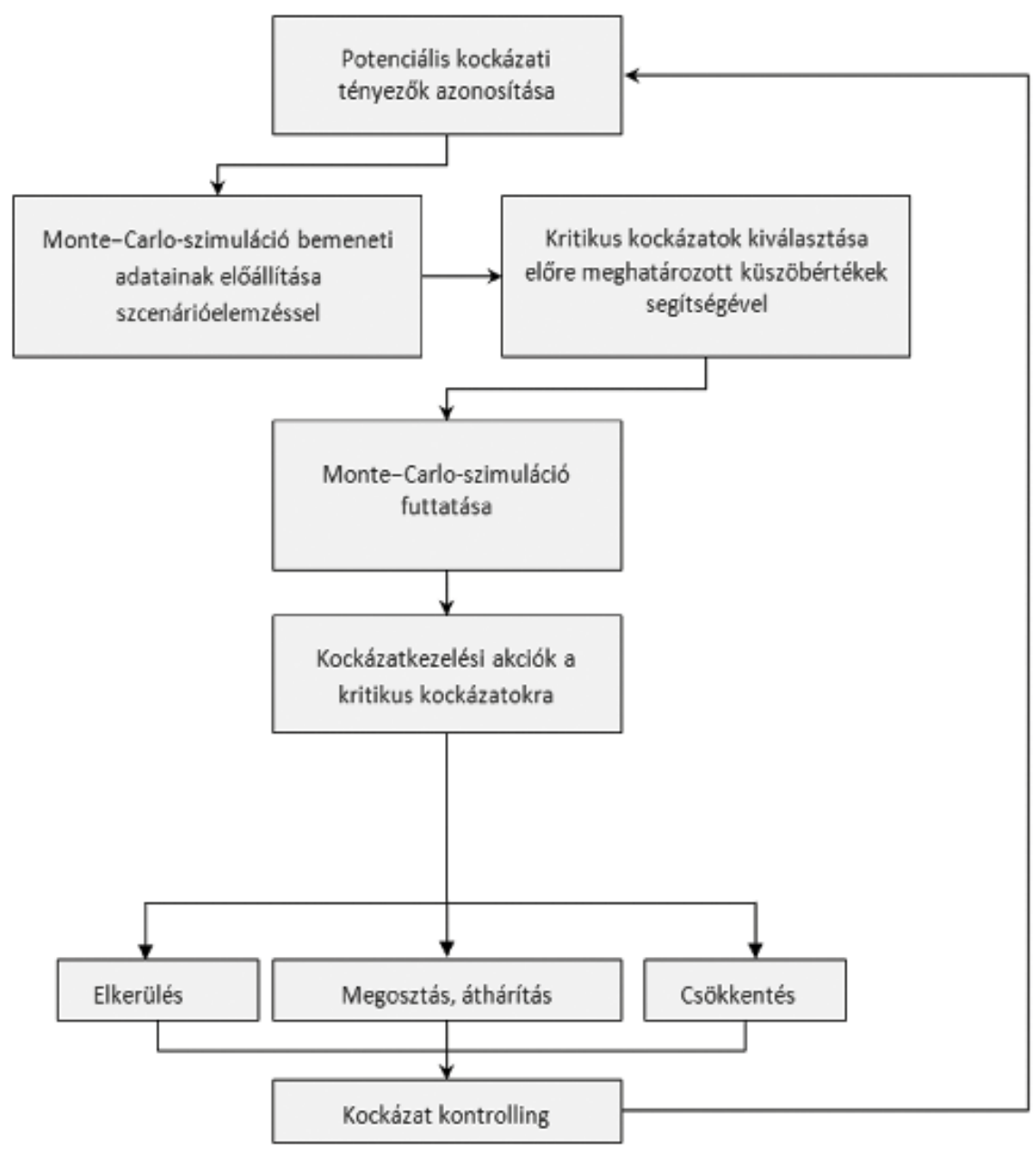

Az 1. ábrán látható az általam kidolgozott kockázatmenedzsment folyamata.

A következókben tömören összefoglalom ennek az eljárásnak a specialitásait, ami abban az esetben is használható, amikor a múltbeli adatok nem állnak rendelkezésre, vagy alkalmatlanok az elemzés elvégzéséhez. 


\section{A kockázati tényezók meghatározása}

Az elsố feladat a kockázati források/tényezók meghatározása strukturált formában. Álláspontom szerint kockázati tényezô jövốbeli esemény, tevékenység vagy tevékenység elmulasztása lehet, ami a szervezet stratégiai céljait pozitív vagy negatív irányban befolyásolhatja.

A kockázati tényezók feltárásához múltbeli adatok hiányában valamilyen ,szellemi alkotástechnikai” eljárás (mint pl. a brainstorming, Papp, 2002) alkalmazását javaslom. A feladatot workshopok keretében célszerú elvégezni, amely néhány órától akár egy teljes napig tarthat, a feladat természetétól függóen. Az elért eredményt jelentősen befolyásolja a workshop résztvevőinek összetétele. Fố szabályként fogalmazható meg, hogy a szakértóknek a kockázatfelmérés tárgya szempontjából minden releváns szakterületet képviselniük kell. Emellett lényeges a sokéves gyakorlati tapasztalat, az összefüggésekben való gondolkodás, valamint a csapatban való együttmúködés készsége.

Múltbeli adatok hiányában különbözố potenciális kockázati tényezóket tartalmazó adatbázis hasznos segítség lehet a kockázati tényező́k meghatározásánál (de Bakker et al., 2010; Bannermann, 2008; Loosmere et al., 2006; Ohtaka - Fukuzawa, 2010), amely testre szabható az adott szervezet igényeinek megfelelően. Ilyen adatbázisok nagy számban érhetốk el a kockázatmenedzsment-szakirodalomban (lásd pl. Chow - Cao, 2008; Hartman - Ashari, 2002; Lind - Culler, 2011; Summer, 2000). Részben ezekre az adatbázisokra támaszkodva kialakítottam egy speciális kockázati adatbázist, amely különösen a stratégiai célok megvalósulását befolyásoló kockázatok felmérése során használható hatékonyan.

\section{Kvantitatív kockázatértékelés}

A következő lépés az elôzôekben azonosított kockázati tényezốk bekövetkezési valószínúségének és hatásának számszerúsítése. A következókben be fogom mutatni, hogy az általam kidolgozott módszer miként szolgáltathat input adatokat az egyik kvantitatív kockázatértékelési technikához, a Monte-Carlo-szimulációhoz (Herz, 1964).

A gyakorlati alkalmazást egy beruházási projekt példáján keresztül szemléltetem. A szimuláció használható pl. a beruházási javaslatok értékelése kapcsán a pénzáramlás nettó jelenértékének kiszámításához (Brealy - Myers, 1993) ${ }^{1}$, valamint a beruházások megvalósítása során annak elősegítésére, hogy a beruházások a tervezett határidốre és a tervezett költségkerettel valósuljanak meg (Grey, 1995).

\section{A beruházási javaslatok értékelése}

$\mathrm{Az}$ elsô feladat az adott beruházás cash flow-modelljének megalkotása és a kockázatelemzés előtti kalkuláció elvégzése (célértékek meghatározása). A következô lépés a cash flow-kalkuláció egyes elemeihez tartozó kockázati tényezók azonosítása. Az azonosítás workshopok keretében, szakértók részvételével történik.

Miután a kockázatok azonosítása megtörtént, minden egyes kockázati tényezóhöz maximum négy különböző szcenáriót/forgatókönyvet rendelünk (Watchorn, 2007). Múltbeli adatok hiányában a következő feladat minden egyes szcenárió esetében a bekövetkezési valószínúség és hatás becslése. Ez a tevékenység is - szakértôk többéves tapasztalatát felhasználva - workshopok keretében történik. Fontos megjegyezni, hogy a maximum négy szcenárió bekövetkezési valószínúségének összege nem haladhatja meg a 100\%-ot, mivel feltételezzük, hogy az egyes szcenáriók egymást kizáróak. A hatás pedig a lehetséges pozitív vagy negatív irányú eltérést méri a kockázatelemzés elótt kalkulált értékhez képest (azaz a célértékhez képest), ha az adott kockázat bekövetkezik. Nagyon fontos a becslés indoklása. Ennek egyik oka, hogy az indoklás elkészítése arra kényszeríti a becslést készítôt, hogy alaposan végiggondolja a becslés folyamatát, így növelve annak esélyét, hogy a becslés minél inkább reális legyen. Ennek során törekedni kell arra, hogy a becslés minél több tényszerú adaton alapuljon, illetve lehetóség szerint tartalmazzon olyan algoritmusokat, amely alapján a döntéshozó egyértelmúen el tudja dönteni, hogy az adott értékelés eredménye mennyire tekinthető megalapozottnak. Természetesen bármennyire is gondosan végzik a szakértốk az értékelést - a kockázat természetéból adódóan, ti., hogy a kockázat a jövoóben következik be - sohasem lehet garantálni, hogy ténylegesen a szakértói becslésben leírtak fognak bekövetkezni. Amennyiben a szakértôknek a tendenciákat helyesen sikerül felrajzolniuk, már nagyon sokat tettek annak érdekében, hogy a kockázatok sajátosságait megértsék, és ezt világosan tudják kommunikálni a döntéshozók számára is. A másik ok pedig az, hogy így lehetővé válik, hogy egy késốbbi idôpontban figyelembe lehessen venni a korábbi értékelés során megfogalmazott indoklásokat, amelyek segíthetik a szakértóket abban, hogy az idóközben megjelenő új információk tükrében hol kell a korábban elvégzett értékeléseket módosítani.

A következő́kben vizsgálni kell, hogy van-e kölcsönhatás/korreláció az egy vagy több cash flow-elemhez hozzárendelt kockázati tényezók között (Hunyadi et al., 1993). Ha igen, akkor annak milyen az iránya és az erôssége. ${ }^{2}$ A feladat nehézségét ismét az adja, hogy nem állnak rendelkezésre múltbeli adatok, ame- 
lyek felhasználásával statisztikai vizsgálatokat végezhetnénk a két tényezố közötti kapcsolat irányának és erôsségének meghatározására. Ezért közelítésre van szükség. A gyakorlati életból szerzett tapasztalataimat felhasználva úgy gondolom, hogy a gazdaságban tökéletes korrelációról általában nem lehet beszélni. Például, ha egy termék ára 10\%-kal nô, általában annak nem egyenes következménye, hogy a termék iránti kereslet 10\%-kal csökken, még az is elképzelhetô, hogy a termék iránti kereslet egyáltalán nem, vagy csak az áremelés mértékénél jóval kisebb mértékben csökken. Gyakorlati tapasztalataimat is figyelembe véve pragmatikus okokból önkényesen tételezzük fel, hogy két lehetséges tényezô között a kapcsolat intenzitása maximum $\pm 0,6$ lehet a legerôsebb kapcsolat esetében is. Így a workshopon részt vevố szakértő́knek tulajdonképpen csak azt kell eldönteniük, hogy a kapcsolat két tényezố között erős, közepes vagy gyenge a -0,6-tól a +0,6ig terjedő tartományon belül. Például, ha az intenzitás erôs, akkor a kapcsolat mértéke $\pm 0,5$ vagy $\pm 0,6$ lehet, ha közepes, akkor $\pm 0,4$ vagy $\pm 0,3$, ha gyenge, akkor $\pm 0,2$ vagy $\pm 0,1$ lehet az érték. Természetesen arra nincs semmilyen megtámadhatatlan bizonyíték, hogy a kapcsolat intenzitásának értéke valóban nem lehet magasabb mint $\pm 0,6$, így nem lehet az intenzitás mértékét pontosan meghatározni, de továbbra se feledjük: nem állnak rendelkezésre, vagy nem elegendő mennyiségben állnak rendelkezésre múltbeli adatok. Ugyanakkor végeztem a vizsgálatokat $\pm 0,6$ intenzitásánál nagyobb értékekre is, és azt tapasztaltam, hogy a kockázat egyik mérôszáma esetében, a szórás mértékében nem következett be olyan jellegú változás, amely a kockázatkezeléssel kapcsolatos döntést alapvetốen befolyásolta volna. A közeljövő́ egyik kutatási iránya lehet azonban az intenzitásbecslés további vizsgálata.

A következő lépés az egyes cash flow-elem esetében a célértékhez képest az eltérés várható értéke és a szórás meghatározása, felhasználva a szcenárióelemzés során megadott becsléseket. Ezek az információk felhasználhatók lesznek a Monte-Carlo-szimuláció során input adatként, melyet majd a késóbbiekben ismertetek.

Az eltérés várható értéke és a szórás más célra is használható: nevezetesen a kritikus kockázatok (kockázati tényezők) kiválasztására. Felfogásom szerint ugyanis nem kell minden kockázatot kezelni, mivel a kockázat kezelésének költsége esetleg nagyobb lehet annál a hatásnál, mint amit kezelni akarunk. A kritikus kockázatok kiválasztására szintén speciális szabályt alkalmazunk. Ennek a szabálynak az értelmében egy kockázat akkor kritikus, ha az eltérés várható értéke és/vagy a relatív szórás ${ }^{3}$ értéke magasabb, mint egy korábban meghatározott küszöbérték. Nem létezik pontos képlet a kü- szöbérték kiszámítására. A kockázatelemző tapasztalata határozza meg, hogy hol húzza meg a határokat. A cikk második felében be fogom mutatni az esettanulmány kapcsán, miként lehet a küszöbértékeket definiálni.

A Monte-Carlo-szimuláció input adatainak megadása során - múltbeli adatok hiányában - a fent javasolt módszer segíthet növelni az egyes cash flow-elemekhez (független valószínúségi változók) a legalkalmasabb valószínúségi eloszlási görbe kiválasztásának esélyét, valamint az adott görbe várható értékének és szórásának meghatározását. Ez az oka, amiért elsốként a szcenárióelemzést végezzük, és annak befejeztével futtatjuk csak a Monte-Carlo-szimulációt.

A következő feladat kiválasztani a függő valószínúségi változót ${ }^{4}$, amely lehet pl. a beruházás cash flowkalkulációjának nettó jelenértéke.

Ha minden input adat rendelkezésre áll, akkor futtathatóvá válik a Monte-Carlo-szimuláció. Ehhez előzetesen azonban még be kell állítani az iterációk számát, azaz meg kell határozni, hogy hány kísérlet alapján álljon elô a függó változó valószínúségi eloszlási görbéje. Tapasztalataim szerint az iterációk számát 1000 és 5000 között célszerú beállítani, hogy a kockázatfelmérés eredményére támaszkodva kellően megalapozott döntést lehessen hozni.

Amikor ezt a számot eléri a szimuláció, akkor elôáll a nettó jelenérték valószínúségi eloszlása az összes jellemző statisztikai értékkel (várható érték, szórás, terjedelem stb.). ${ }^{5} \mathrm{Az}$ így kapott valószínúségi eloszlás tartalmazhatja a célértéket is (a kockázatelemzés elótti nettó jelenérték), így lehetségessé válik, hogy összehasonlítsuk a kockázatelemzés előtti és utáni kalkuláció eredményét. Mindez a piacon kapható számítógépes szoftverek támogatásával könnyen megvalósítható. ${ }^{6}$

\section{Beruházási projektek megvalósításának értékelése}

Az első lépés a kockázatfelmérés elvégzésére alkalmas magas szintú projektterv elkészítése. A projektterv tartalmazza az egyes tevékenységeket, a tevékenységek időtartamát, logikai kapcsolatokat a tevékenységek között és részletes erőforrás- és költségtervet (Grey, 1995), valamint a kockázatelemzés előtti értékeket (célértékek). Mivel a megvalósítás során tevékenységalapú kockázatfelmérést végzünk, így a Monte-Carloszimuláció során egyes projekttevékenység idôtartama és költsége lesz a független valószínúségi változó.

A következő lépés a magas szintü projektterv egyes tevékenységeinek időtartamára vagy a megvalósítás költségére ható kockázati tényezók azonosítása az általam kifejlesztett speciális kockázati adatbázis felhasználásával. 
A kockázati tényezốk azonosítása után a következô feladat azok értékelése szcenárióelemzéssel, valamint a valószínúségi változók közötti kölcsönhatások vizsgálata a beruházási javaslatnál leírtakkal teljesen megegyező módon (Cleden, 2009; Nakatsu - Iacovou, 2009).

A szcenárióelemzés adatait felhasználva történik az egyes projekttevékenység idôtartama/költsége valószínúségi eloszlási görbéjének kiválasztása a beruházási javaslatok értékelésénél leírtakkal teljesen megegyező módon. A gyakorlatban a leggyakrabban előforduló eloszlások a béta, gamma, háromszög, lognormális és normális eloszlás (Evans et al., 1993). Ezután az adott eloszlás jellemzố paramétereit (várható érték, szórás) kell kiszámítani a szcenárióelemzés eredményeinek felhasználásával.

Amikor minden input adat rendelkezésre áll, a szimuláció futtatható és a projekt kritikus útjának hoszsza és/vagy teljes költsége kiszámítható abból a nagy mennyiségú véletlenszerú adatból, amely a tevékenységek időtartamához/költségéhez rendelt valószínúségi eloszlásokból állt elô. Ez a piacon fellelhetô számítógépes programok segítségével oldható meg (Grey, 1995). A szimuláció alkalmazása növeli az esélyét annak, hogy a projektet időben és a költségvetés keretein belül fejezhessük be.

\section{A kockázatok kezelése}

A következő lépés a kockázatmenedzsment folyamatában megfogalmazni és végrehajtani a kockázatkezelő akciókat a korábban kiválasztott kritikus kockázatokhoz. A cél elkerülni, megosztani, áthárítani vagy viselni a kockázatokat a kockázatkezelési eszközök segítségével (Haris, 2009).

Fontos hangsúlyozni azonban azt, hogy a kockázatkezelési akcióknak nem az a célja, hogy megszüntessék a kockázatokat, hanem inkább a kockázati kitettségnek a döntéshozók számára már elfogadható szintre való csökkentése.

A kockázatkezelési akciók megfogalmazása során ezért célszerú a következőkre figyelni:

Az elemei „quick-win” jellegúek, azaz gyorsan végrehajthatók legyenek, alacsony ráfordítással, és az eredményt gyorsan kell, hogy produkálják. A kockázatkezelési akciók végrehajtási költségének alacsonyabbnak kell lennie, mint a kockázat bekövetkezése esetén felmerülő költségeknek.

Tartalmazhat olyan elemeket is, amelyeket már elkezdtek megvalósítani. Ez akkor fordulhat elő, amikor a szakértók az elemzés során olyan akciókat fogalmaznak meg, amelyek megvalósításáról a kockázatfelmé- rés előtt már intuitív módon döntöttek, és a döntés helyességét a kockázatfelmérés is alátámasztotta.

A kockázatkezelési akcióknak mérhetôeknek kell lenniük. Egy beruházási projekt esetében a javasolt kockázatkezelési akciók megvalósításával nố az esélye a projekt idóben történó befejezésének és a meghatározott költségek kereten belüli megvalósításának, vagy sikerül biztosítani az elvárt projektmegtérülést. Más szóval: a javasolt kockázatkezelési akciók megvalósításával lehetôvé válik a célértékek elérése vagy megközelítése.

Fontos, hogy a jelzett akciók mellé a végrehajtásért felelôs kockázatgazdákat jelöljenek ki. A kockázatgazda lehet személy vagy szervezet is.

A következókben a lehetséges kockázatkezelési eszközök részletesebb bemutatására kerül sor (Balaton et al., 2005).

Kockázatok elkerülése - Akkor alkalmazzák, amikor a kockázat gyakran következik be, és bekövetkezés esetén hatása nagy (Pata - Tatai, 2008). Jó példa erre a megelőző akciók adott folyamatba ágyazása (múszaki vagy életvédelmi, szưrő/ellenőrző rendszerek) megelőzô célzattal.

Kockázatok csökkentése - Egyrészról cél lehet a kockázat bekövetkezési valószínúségének csökkentése olyan eszközökkel, amelyek megakadályozzák, hogy a kockázat bekövetkezhessen (Csipkés, 2010). Jó példa erre a „Dohányozni tilos!” tábla elhelyezése a benzinkutaknál, amely elősegítheti azt, hogy ne következzen be robbanás. Vannak azonban olyan esetek, amikor nincs befolyásunk a kockázat bekövetkezésére, ilyenkor csak a hatást lehet csökkenteni abban az esetben, ha a kockázat bekövetkezik. Ilyen eset lehet például a sztrájk. Ilyenkor is gondoskodni kell a dolgozók bejuttatásáról a munkahelyekre. Ezt szolgálhatja az üzletmenet-folytonossági terv.

Kockázatok áthárítása vagy megosztása - Azt jelenti, hogy találunk egy külsố partnert, aki egy adott összeg fejében átvállalja az esetleges múködési zavarokból adódó veszteségeket. A kockázat áthárítására tipikus példa a biztosítás, de egy fővállalkozó megbízása a projekt kivitelezésében is jó példa lehet erre (Görög, 2008).

Kockázatok viselése - Ebben az esetben a kockázatokat nem lehet elkerülni vagy áthárítani, vagy a kezelésük költsége aránytalanul magasabb lenne a várható hatásukhoz képest. Ilyenkor a döntéshozó tudatosan vállalja a kockázatokat.

A kockázatkezelési akciók könnyebb megfogalmazhatósága érdekében kidolgoztam a kockázatkezelési akciók adatbázisát, amely ötvennél több különböző akciót tartalmaz. 


\section{Kockázatkontrolling}

A kockázatmenedzsment folyamatának utolsó lépése a kockázatkezelési akciók végrehajtása idején végzett kockázatkontrolling-tevékenység, mely három különböző elemet tartalmaz (Boehm, 1989).

A kockázatmenedzsmentet úgy kell tekinteni, mint egy adott pillanatról készült pillanatfelvételt. Így előfordulhat, hogy már másnap az elemző tudomására jut egy olyan új információ, amely alapvetốen befolyásolja az elemzés eredményét. Ilyenkor érdemes az egész felmérést újra elkészíteni. Természetesen a megismételt elemzést már sokkal gyorsabban meg lehet valósítani, mivel az elvégzendő feladat alapvetően az új információból eredô információk értékelésére koncentrálódik. Természetesen a kritikus tényezók változhatnak, amely maga után vonhatja a kockázatkezelési akciók módosulását is.

A kontrolltevékenység második eleme a kockázatkezelési akciók megvalósításának nyomon követése. Ez klasszikus kontrolltevékenységet jelent, mely az alábbi feladatok megoldását foglalja magában: helyzetfelmérés, a hatás elemzése, módosítás a hatáselemzés alapján, az utasítások és a módosítások közlése és azok végrehajtása.

A kontrolltevékenység harmadik komponense a terv-tény elemzés végrehajtása (Maczó, 2007) rögtön azután, hogy a kockázatkezelési akciók végrehajtása befejezôdött. Cél a kockázatelemzés elốtti és utáni állapotok összehasonlítása. A terv-tény elemzés jelenti a költség-haszon elemzés inputját (Fekete, 2011), amely képes mérni a kockázatkezelés hatékonyságát és hatásosságát.

\section{Integrált kockázat- menedzsment-rendszer}

A cikk bevezetôjében a bizonytalanság és a kockázat fogalmának különbözó megközelítéseit mutattam be.

A bizonytalanság és a kockázat rengeteg forrásból származhat, pl. pénzpiacok bizonytalansága, hitelkockázatok, szabályozási és jogi kockázatok, balesetek, természeti csapások ugyanúgy, mint a nem szándékos emberi hibák stb. (Farkas - Szabó, 1998).

Értelmezésem szerint a különbözô típusú kockázatok bekövetkezése a szervezet stratégiai céljait pozitív vagy negatív irányban befolyásolhatja. Annak érdekében, hogy az összes stratégiai cél a legnagyobb valószínúséggel kerülhessen megvalósításra, létfontosságú, hogy minden típusú kockázatot integrált módon értékeljünk és kezeljünk. Ez azt jelenti, hogy a különbözô típusú kockázatok közötti kapcsolatokat is számításba kell venni. Ezt a cél szolgálja az integrált kockázatmenedzsment-rendszer kialakítása a különbözô szervezeteknél.

Az integrált kockázatmenedzsmentnek az alkalmazó szervezet minden tevékenységére ki kell terjednie. Fontos, hogy felmérjünk minden olyan kockázatot, amely közvetlenül befolyásolja az adott szervezet valamennyi tevékenységét. Ennek révén lehetôvé válik az adott szervezet stratégiai céljait leginkább befolyásoló kockázatok feltérképezése, a hatékony kockázatkezelés megvalósítása és a kockázatkezelés hatékonyságának visszamérése (Australian RM Standard, 2004; PMBOK, 2008; ISO 31000, 2009).

Az integrált kockázatmenedzsment-rendszer múködtetése nagymértékben hozzájárulhat az adott szervezet valamennyi tevékenységét befolyásoló kockázati tényezók időben történô azonosításához, a kockázatok besorolásában történố változások folyamatos nyomon követéséhez, így segítve a kockázatkezelési akciók hatékony megvalósítását.

A 2. ábra azokat felhasználói szinteket szemlélteti, ahol az integrált kockázatmenedzsmentet célszerú alkalmazni az adott szervezet üzleti döntései során (2. ábra).

2. ábra

\section{Integrált kockázatfelmérés alkalmazási területei}

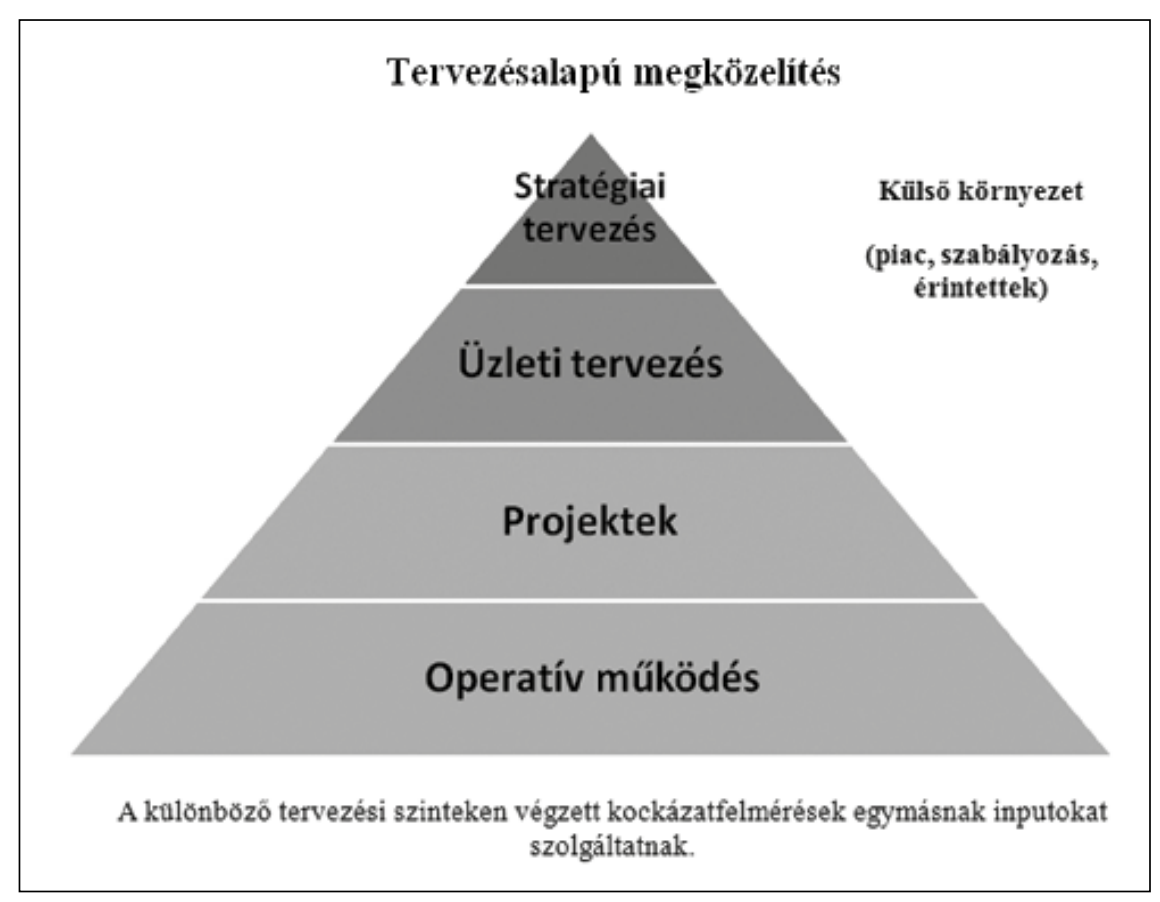


Látható a 2. ábrán, hogy a stratégiai és a projektkockázatok kezelése a tervezés különbözô szintjein valósul meg. Fel kell azonban hívni arra a figyelmet, hogy a különbözô szintek a kockázatmenedzsment gyakorlati megvalósítása szempontjából is hatnak egymásra, pl. a stratégiaalkotás során azonosított kockázatok megjelenhetnek az üzleti (költségvetés) tervezés és a projekttervezés szintjén is.

\section{Kockázatelemzés a stratégiai tervezés szintjén}

A vállalati stratégia nagyon sok információ feldolgozásának eredményeképpen jön létre. A piaci hatások, a technológiai trendek, a versenystratégia, a szabályozások különös jelentőséggel bírnak a vállalati stratégiaalkotás folyamatában (Anderson - Frigo, 2012). A kockázatmenedzsment segíthet a stratégiai célok megfogalmazásában. A kockázatok azonosítása alapvetően a szervezet belsố múködéséból származó gyengeségekre és a külső környezetből eredő veszélyekre és lehetőségekre összpontosít.

A stratégiai tervezés második fázisa a stratégia megvalósítása. Itt a feladat a korábbi fázisban meghatározott stratégiai célok akciótervben történô lebontása, mely inputot szolgáltat az üzleti (költségvetési) terv elkészítéséhez. A stratégia megvalósítása során rendkívül fontos, hogy mérhetô legyen annak hatékonysága. Ebból a célból különbözô indikátorokat és azok célértékeit szükséges meghatározni. A kockázatmenedzsment feladata pedig a célértékektól való eltérést eredményezô kockázatok feltárása és értékelése (Frigo - Anderson, 2011).

\section{Kockázatmenedzsment az üzleti (költségvetési) tervezés szintjén}

A vállalati/intézményi szintú bevételek és a bevételekhez kapcsolódó múködési és beruházási költségek tervezése folyik ezen a szinten.

Itt a feladat az adott szervezet környezetében levô sokoldalú kapcsolatrendszer modellezése, amely a terv bevételi és kiadási oldalára ható kockázatok azonosításában és értékelésében jelenik meg. Mindez a terv alátámasztottságát növelheti (Ai et al., 2012). Üzleti környezetben múködő vállalatok esetében kockázatelemzés segítségével meghatározható, hogy mit kellene tenni azért, hogy elérjék a kívánt nyereséget.

A módszer alkalmazható a vállalatok immateriális javai költségeinek tervezése során is. Ez a kockázatmenedzsment egy igen szokatlan, újszerú alkalmazása (Boda - Szlávik, 2005). Az integrációt az a tény is igazolja, hogy a vállalatok/intézmények tôkeösszetétele változó. A látható tókeelemek mellett a láthatatlan tôkeelemek jelentősége is folyamatosan nô.
A kapcsolati tóke (kapcsolat a vevókkel és szállítókkal), a szervezeti tôke (belsô üzletmenet) és az alkalmazottak szakértelme is mind ez utóbbi kategóriához tartozik. A jövőben a láthatatlan tókeelemek súlya egyre inkább növekvő lesz, különösen azokban a szektorokban, ahol a folyamatos innováció elengedhetetlen. A láthatatlan tôkébe történô beruházás kockázata azonban nagyobb, mint a tárgyi eszközökbe történô beruházás. Elég, ha pl. belegondolunk abba, hogy az alkalmazottak szakértelmébe történô invesztálás elveszik, ha az alkalmazott kilép. Erre alapozva elengedhetetlen, hogy azonosítsuk és értékeljük azokat a kockázatokat, amelyek az efféle beruházásokhoz kapcsolódnak.

\section{Kockázatmenedzsment a projekttervezés szintjén}

Általában minden projekt esetében szükséges kockázatelemzést készíteni. Természetesen az ezen a szinten végzett elemzés különbözik attól, amit a stratégiaalkotás és az üzleti/költségvetési tervezés szintjén végeznek. A projektek kockázatmenedzsmentjének egyik alkalmazási lehetôsége a különböző európai uniós alapok forrásaiból megvalósuló projektek döntéselókészítése és végrehajtása.

A pályázatok megnyerésével, elfogadásával, értékelésével, ellenőrzésével kapcsolatos információkat a tenderkiírások tartalmazzák (Kovács, 2007). Ezek nagyon különbözőek lehetnek annak függvényében, hogy melyik operatív programhoz kapcsolódó pályázaton alapulnak. A tender dokumentációjának értékelése során a döntést befolyásoló tényezók: a projektterv kialakításának részletezettsége, a szakmai és pénzügyi tartalom és a fejlesztés költségeinek hatékony felhasználása. Lényeges továbbá annak bemutatása, hogy a megvalósítandó projekt összhangban van-e a pályázó stratégiai céljaival, illetve a stratégia megvalósítása kapcsán kapcsolódik-e hozzá másik operatív program keretében megvalósuló projekt.

A kockázatelemzés elvégzése és a kockázatkezelési akciók meggyőzhetik a tendert elbíráló bizottságot arról, hogy a pályázó alaposan felmérte a projekt végrehajtásának következményeit, elemezte a lehetséges kockázati tényezóket, és van saját koncepciója azok kezelésére.

Itt kell megjegyeznünk, hogy az integrált kockázatmenedzsment nemcsak a fenn felsorolt területeken alkalmazható, hanem a belső ellenôrzés, IT-kontroll (Cepa - Werner, 2009), egészségvédelem, munkavédelem, üzletmenet-folytonossági terv, katasztrófaelhárítási és helyreállítási terv készítésének stb. is részét képezheti (Machiowiak, 2012). 


\section{Esettanulmány: Kockázatmenedzsment egy termelôüzemnél}

Az esettanulmány azt hivatott illusztrálni, hogy a kockázatelemzés miként segítheti egy villamos energiát termelő vállalat. különböző stratégiai céljainak teljesülését.

Abban az esetben, ha a vállalat nem képes a hosszú távú értékesítési szerződésében vállalt villamosenergiamennyiséget elóállítani előre nem tervezett termeléskiesés miatt, a kiesett mennyiséget külsố piacról kell beszereznie, amelynek beszerzési ára lényegesen magasabb lehet, mint a villamos energia elóállításának önköltsége. E díjtételen túl, a termelés elmaradásából adódóan jelentős árbevétel-kiesés is jelentkezik, így ebben az esetben a vállalat nyeresége szignifikánsan csökkenni munkatársai részletes projekttervet készítettek, amely több mint 6500 különböző tevékenységet tartalmaz. A technológiai egységek szétszerelését követôen számtalan olyan elôre nem várt esemény fordulhat elő, amely a feladatok végrehajtásának tervezett hosszát megnövelhetik. Az elmúlt évek tapasztalatain alapulva elmondható, hogy a karbantartási munkák átlagos csúszása általában három nap, ami közvetlenül több százmilliós árbevétel-kiesést von maga után.

Ezért minden eszköz fontos lehet a vállalat számára, ami hozzájárul a lehetséges veszteség elkerüléséhez vagy legalább csökkentéséhez. Egyik ilyen lehetséges eszköz a kockázatmenedzsment, amely abban segíthet, hogy a jövőbeni potenciális veszteség okait feltárja, és ezáltal csökkenteni képes a kritikus kockázatok

Egyszerúsített projektterv

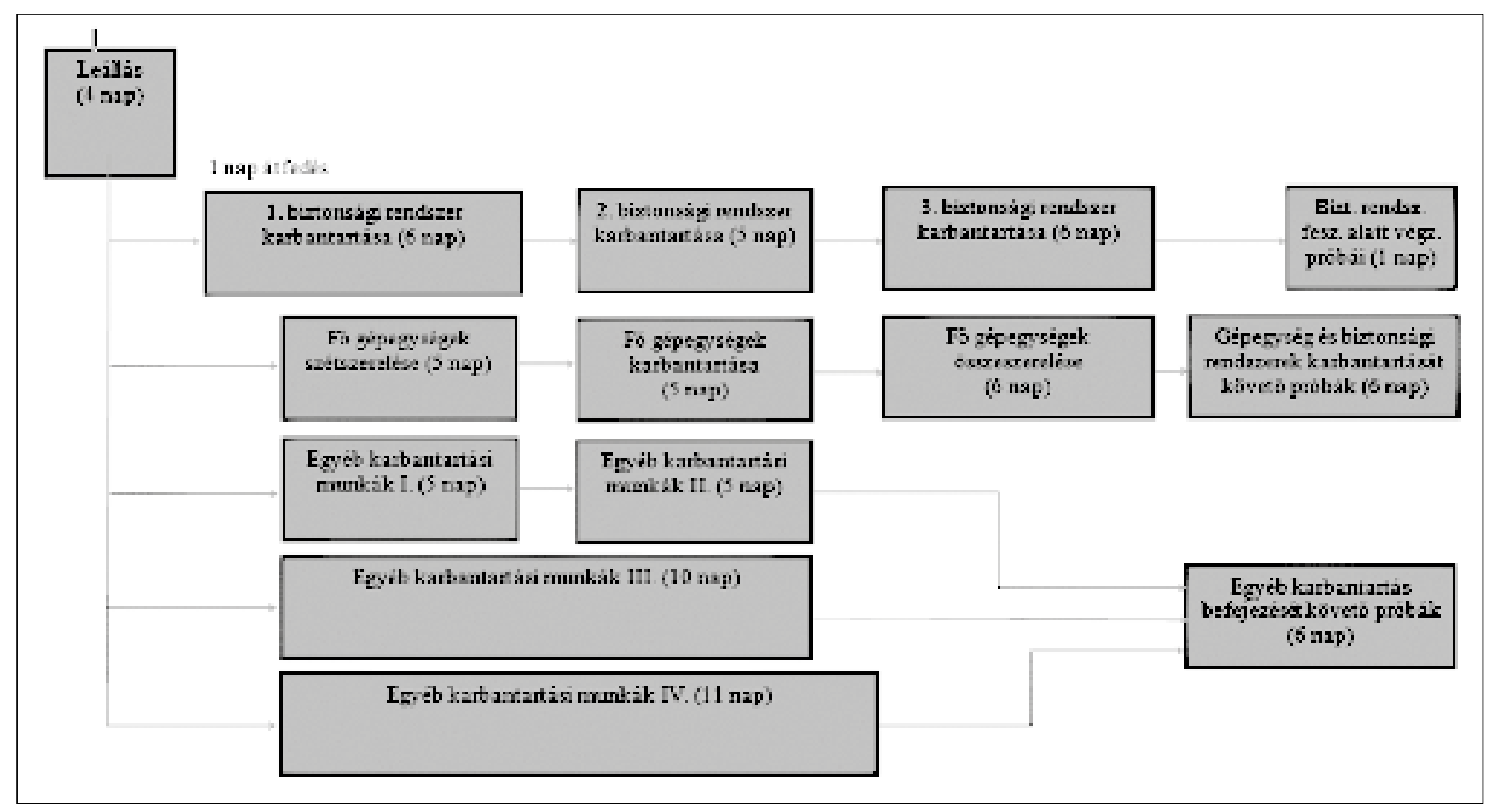

fog. Ezért alapvetố érdeke a vállalatnak, hogy meghatározza mindazokat a kockázatokat, amelyek a tervezett karbantartási hosszokat, a nem tervezett kiesést, illetve az üzemszünetet okozhatják, és modellezni kell azok hatását a termelési terven keresztül a vállalat üzleti tervére.

\section{Az esettanulmány célja}

A termelőegységeket rendszeres idóközönként le kell állítani tervszerú karbantartás céljából. A karbantartási üzemszünet alatt megelőző és korrigáló karbantartási munkálatok folynak, és jellemzóen 26 nap alatt végezhetốk el. A feladatok elvégzéséhez a vállalat bekövetkezési valószínúségét és/vagy hatását. Mindez stratégiai nézôpontból a következő kérdés megválaszolásában adhat segítséget: hogyan érhetố el a villamosenergia-termelô egységek stratégiai célokat támogató rendelkezésre állása? Más szóval: milyen módon biztosítható a villamosenergia-termelés maximalizálása?

Az esettanulmány célja a karbantartási munkák tervezett átfutási idejét befolyásoló kockázatok feltárása és értékelése, és ezek hatásának modellezése a vállalat termelési és eredménytervére, és ezen keresztül a stratégiai célok teljesülésének előmozdítása. Az esettanulmányban feltüntetett adatok nem valósak, csak illusztrációk. 
A munka során fontos előfeltétel volt a karbantartási munka elvégzésére a vállalat munkatársai által készített projektterv jóságának elfogadása. Másképpen fogalmazva: nem volt cél annak vizsgálata, hogy miként lehetne például jobb munkaszervezéssel a karbantartási munka átfutási időtartamát rövidíteni.

\section{A kockázatelemzés fóbb lépései}

Az elsô lépés a kockázatfelmérés hatékony elvégzését lehetôvé tévô projektterv elkészítése. Erre azért van szükség, mert a vállalat szakemberei által készített projektterv több ezer tevékenységet tartalmaz. Nyilvánvaló, hogy ilyen nagyszámú tevékenységek esetén a kockázatfelmérés idôigénye kezelhetetlenül magas lenne. Ezért az elsô feladat a tevékenységek számának kezelhetố szintre történô redukálása úgy, hogy az eredeti projektterv tartalma ne sérüljön. Az egyszerúsített projekt a 3. ábrán látható.

Az egyszerúsített projektterv elkészítésének fontos része a tevékenységek közötti logikai kapcsolatok meghatározása, ezt követóen már lehetôvé válik a projektterv kritikus útjának, és ezen keresztül a projekt átfutási idejének meghatározása (Grey, 1995), amely a mintapélda esetében 26 nap.

A következő lépés workshopok keretében szakértők bevonásával a lehetséges kockázati tényezôk hozzárendelése az egyszerúsített projektterv egyes tevékenységeihez. A hozzárendelés workshop keretében történt, amelyen a vállalat szakértôi is részt vettek. A munkát hatékonnyá tette az általam kifejlesztett és rendelkezés- re bocsátott kockázati adatbázis. Ebben az adatbázisban a kockázati tényezóket kockázati csoportokba soroljuk be, pl. jogi kockázatok, technológiai kockázatok, humán erőforrásban rejlő kockázatok, IT-kockázatok, együttmúködési, irányítási etc. kockázatok. A szakértớk részben az elóbb említett kockázati adatbázis felhasználásával körülbelül 10-12 kockázati tényezốt rendeltek hozzá az egyes projekttevékenységekhez.

Következô lépés a szcenárióelemzés végrehajtása volt. Mint már korábban említettem, négy különböző forgatókönyvet lehet meghatározni és értékelni minden egyes kockázati tényezố esetében. Az értékelés során a szakértók megbecsülik az adott szcenárió bekövetkezésének valószínúségét és annak hatását napokban kifejezve, összevetve az adott tevékenység eredetileg tervezett idôtartamával.

A kritikus kockázati tényezók kiválasztása a korábban meghatározott várható érték küszöb- és relatív szórás küszöbértékeken alapul. Azoknál a kockázatoknál, ahol a várható érték vagy a szórás meghaladja a küszöbértéket, kritikusak lesznek.

Könnyen előfordulhat, hogy ugyanazon kockázati tényező különbözố projekttevékenységeknél is kritikus lesz, a kockázatmenedzsmentnek kell kiszúrni ezeket a redundanciákat és konszolidálni a kockázatkezelési akciókat. Ez az egyszerúsítési lépés lehetôvé teszi, hogy csökkentsük a kockázatkezelési akciók teljes költségét, így a kockázatmenedzsment még hatékonyabbá válik. A kockázatkezelési akciók fó célja, hogy segítse az adott tevékenység az eredeti projekttervben meghatározott határidőben történő befejezését.

1. táblázat

Példa a kockázatfelmérésre (illusztráció)

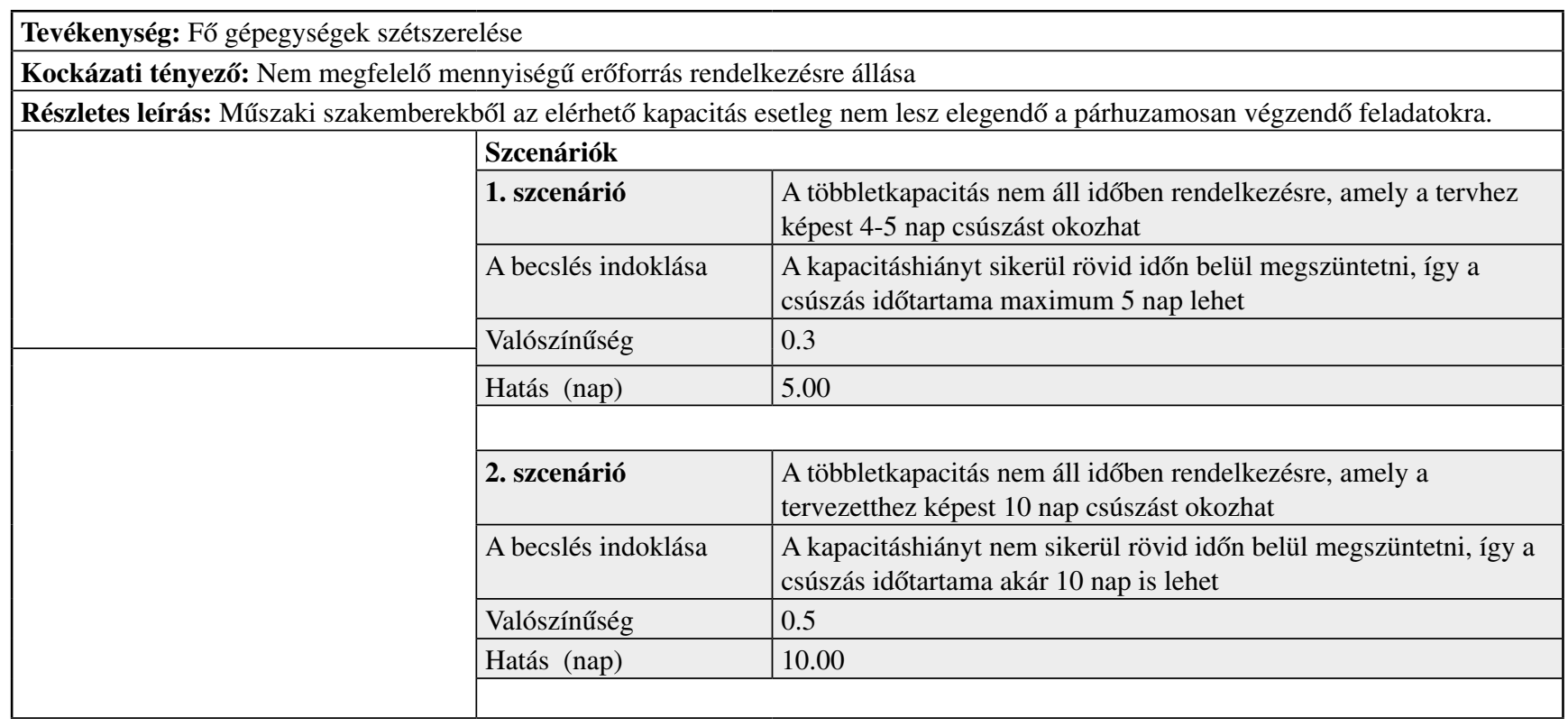




\begin{tabular}{|c|c|c|}
\hline & 3. szcenárió & $\begin{array}{l}\text { A többletkapacitás nem áll idóben rendelkezésre, amely a } \\
\text { tervezetthez képest } 15 \text { nap csúszást is okozhat }\end{array}$ \\
\hline & A becslés indoklása & $\begin{array}{l}\text { A projektvezető csak nagyon későn reagál a kapacitáshiányra, } \\
\text { így a csúszás időtartama, akár } 15 \text { nap is lehet }\end{array}$ \\
\hline & Valószínúség & 0.2 \\
\hline & Hatás (nap) & 15.00 \\
\hline $\begin{array}{l}\text { Tevékenység időtartamának várható } \\
\text { értéke (nap) }\end{array}$ & \multicolumn{2}{|l|}{9.5000} \\
\hline $\begin{array}{l}\text { Tevékenység idôtartamának szórása } \\
\text { (nap) }\end{array}$ & \multicolumn{2}{|l|}{3.5000} \\
\hline Kritikus? & \multicolumn{2}{|l|}{ igen } \\
\hline Kockázatkezelő akció leírása & \multicolumn{2}{|c|}{$\begin{array}{l}\text { A tervezési tevékenység szigorú kontrollja mellett folyamatos konzultáció a projektirodáva } \\
\text { és a projekttulajdonossal. }\end{array}$} \\
\hline Felelős & \multicolumn{2}{|c|}{ Karbantartási projekt projektvezetője } \\
\hline Határidő & \multicolumn{2}{|c|}{ 2012. január 31.} \\
\hline Megvalósítás becsült költsége & \multicolumn{2}{|l|}{$160000 \mathrm{HUF}$} \\
\hline
\end{tabular}

A karbantartási projekt átfutási idejének valószínúségi eloszlása

a Monte-Carlo szimuláció után

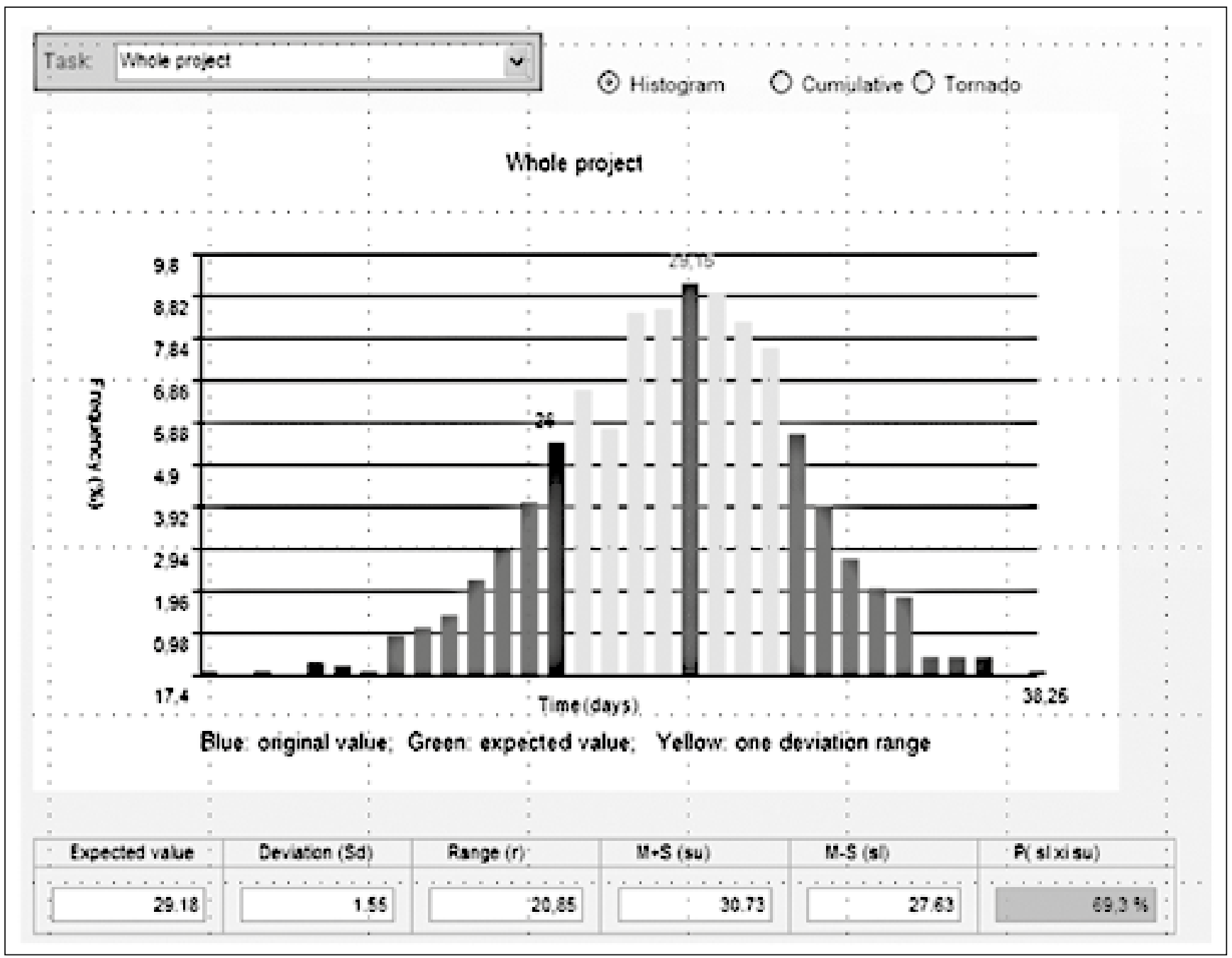


Tornádo diagram: a karbantartás csúszásáért leginkább felelôs tevékenységek

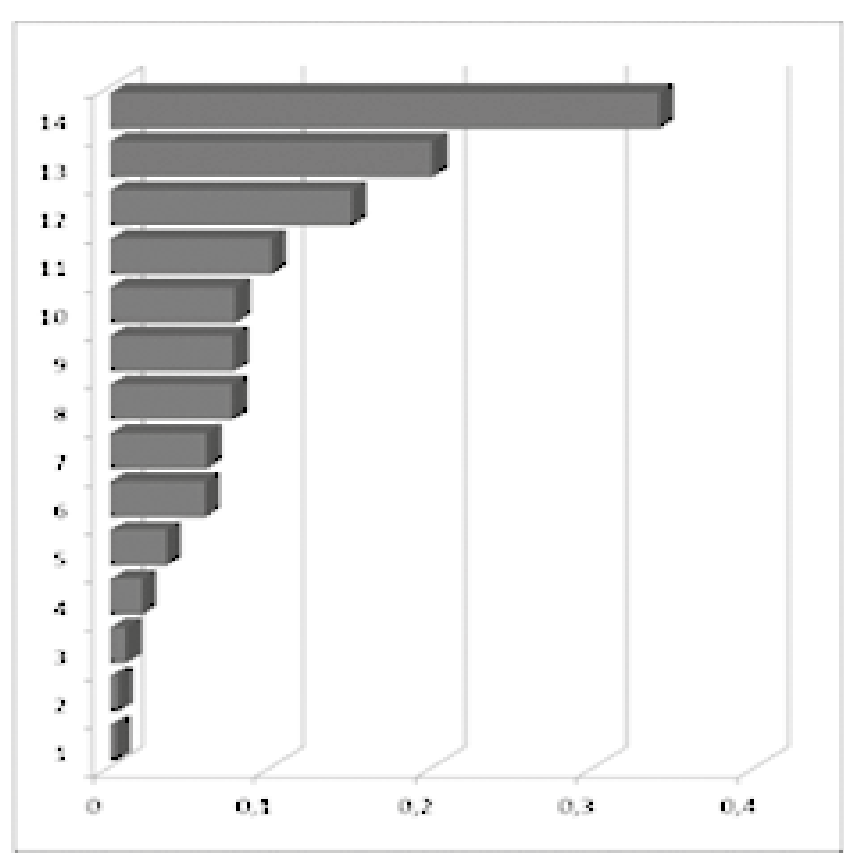

Az 1. táblázatban egy példa látható arra, hogy miként értékelhetốk ki a különböző kockázatok szcenárióelemzés segítségével. A példában található számok csak illusztrációk.

A Monte-Carlo-szimuláció során felhasználjuk a szcenárióelemzés és a véletlenszám-generátor adatait annak érdekében, hogy a karbantartás teljes futamidejének valószínúségi eloszlását megkaphassuk (Eilon Fowkes, 1973). Ez a kockázatértékelés utolsó lépése.

$\mathrm{Az}$ eloszlás várható értéke, szórása, terjedelme és más paraméterei az egyes tevékenységek és a teljes projekt átfutási idejére is (kritikus út hossza) kiszámíthatók (Grey, 1995).

Ha elég múltbeli adat állt volna rendelkezésre a korábbi karbantartási projektek tapasztalataiból, akkor a Monte-Carlo-szimuláció azonnal futtatható lett volna a szcenárióelemzés elvégzése nélkül is.

A 4. ábrán a karbantartási projekt idôtartamára vonatkozó valószínúségi eloszlás látható a Monte-Carloszimuláció futtatása után.

Látható az eredményból, hogy a karbantartás várható időtartama három nappal megnövekedhet, de a

A kifejlesztett modell lényege

6. ábra

\section{Kockézatelemzés elötí állapor}

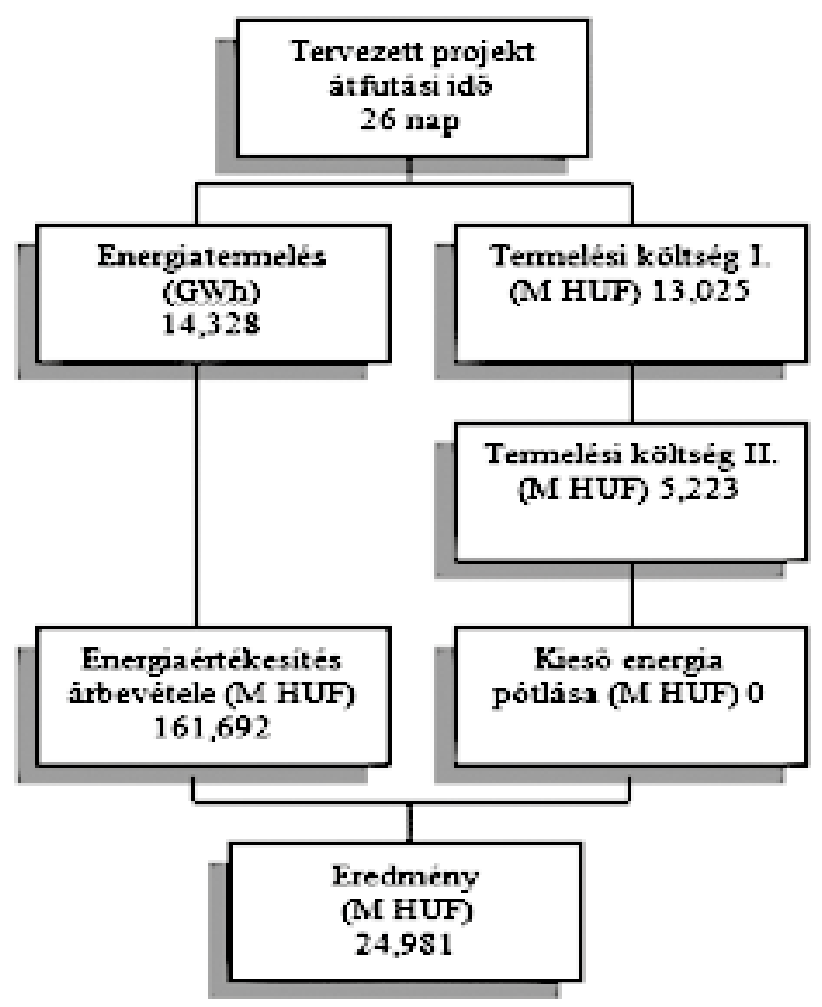

Kockázatelemzés utámi állapot

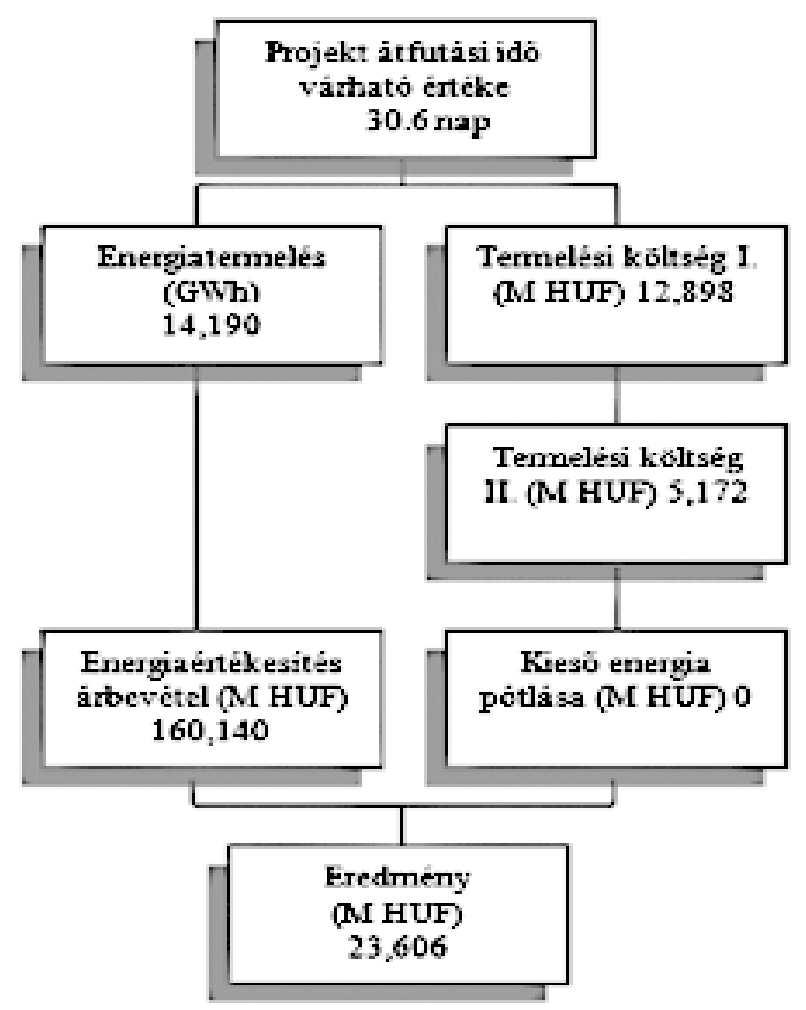


nagy szórás miatt lehetőség van a karbantartásnak az eredetileg tervezett határidő előtt történő befejezésére is. Ez azt jelenti, hogy a projekt nemcsak negatív, hanem pozitív kockázatokat is rejt magában. A pozitív kockázatok tulajdonképpen lehetôségek, amelyeket a vállalat kihasználhat a kockázatkezelő akciók azonnali végrehajtásával.

A Monte-Carlo-szimuláció futtatása után elóáll a tornádó diagram (Barett, 2004).

Ennek a diagramnak a lényege, hogy megmutatja azokat a tevékenységeket, amelyek leginkább felelősek a projekt idóbeli csúszásáért. Ezek azok a tevékenységek, amelyek nagy kockázati kitettségük miatt a legnagyobb mértékben téríthetik el a karbantartás tényleges idôtartamát. Ezért tanácsos elsôként ezeknek a kritikus tevékenységeknek a kockázatkezelési akcióit végrehajtani annak érdekében, hogy az eredetileg tervezett határidô betartható legyen.

A példánál maradva a leállás (13. projekttevékenység) és a karbantartást követố tesztelés (14. projekttevékenység) feladatok azok, amelyek leginkább felelósek a projekt késéséért, ahogy ez az 5. ábrán látható.

A kockázatelemzés eredményeit felhasználva a következő fontos kérdés annak megválaszolása, hogy milyen hatása van a karbantartási munkák késedelmének a villamosenergia-termelésre és a vállalat üzleti eredményére. Egy Excel-makró készült abból a célból, hogy megteremtsük a kapcsolatot a kockázatelemzés eredményei és a termelési terv és az üzleti terv között. Az Excel-makró segítségével lehetővé vált annak modellezése, hogy miként változik az előállított villamos energia (GWh) mennyisége, az egyéb költségek (M HUF) és az adózás elôtti eredmény (M HUF) a kockázatok hatására.

Az Excel-makró használatával megválaszolhatóvá válik pl. az a kérdés is, hogy viszonylag nagy valószínúséggel (60\%) milyen tartományban ingadozhat a villamosenergia-termelés, ha a korábban feltárt és értékelt kockázatok bekövetkeznek. A 6. ábra a kidolgozott modell lényegét mutatja be.

A modell futtatását követően megállapíthatjuk, hogy a karbantartási munka a tervezetthez képesti 3-4 napos késése az adózás elótti eredményt hozzávetóleg milliárdos nagyságrendú összeggel csökkenti.

A kockázatkezelési akciók végrehajtásával lehetőség nyílik azonban arra, hogy a karbantartási munka az eredetileg tervezett határidóig befejezódjön, és így a vállalat elkerülje az ötmillió eurós veszteséget. Természetesen a kockázatkezelő akciók végrehajtása is pénzbe kerül, de azok kivitelezésének költsége csak töredéke annak a veszteségnek, amelyek az akciók végrehajtása nélkül lépnének fel.

\section{A bemutatott modell továbbfejlesztésének lehetséges irányai}

Az elemzések elvégzését követően a következő irányokba célszerú a modellt továbbfejleszteni:

A kockázatfelmérés időtávjának lejártát követôen ajánlatos megvizsgálni, hogy hány darab korábban azonosított kockázat következett be valójában, mekkora ezeknek a valós hatásuk, és vannak-e olyan kockázatok, amelyek bekövetkeztek, de az elemzés során nem azonosították ôket.

Hasznos lenne továbbá költség-haszon elemzést végezni, hogy összehasonlíthatóvá váljanak a kockázatkezelés költségei és a kockázatkezelés által elért megtakarítások. Ez utóbbi jelen esetben azt jelenti, hogy mennyivel sikerül csökkenteni a vállalat árbevétel-kiesését azáltal, hogy a karbantartási munka időtartamának csúszását az eredeti tervhez képest a kockázatkezelési akciók végrehajtásával minimalizáltuk.

A kockázatfelmérés hatékonysága és pontossága javítható a vállalatnál rendelkezésre álló különböző adattárolórendszerek között kialakított interfész kialakításával.

\section{Következtetések}

A következókben az integrált kockázatmenedzsmentrendszer alkalmazásából származó előnyöket foglalom össze az esettanulmány tapasztalatait is figyelembe véve.

A különbözô szervezetek döntéshozói számára kiemelten fontos, hogy teljesüljenek a vállalat stratégiai céljai. Ezért minden olyan kezdeményezést szívesen fogadnak, amelyek segítséget nyújtanak e célok teljesülésének előmozdításához. A bemutatott esetpéldában kiemelt stratégiai cél volt a kereskedelmi szerződésben rögzített villamosenergia-mennyiség átadása az üzleti partner számára. Ezt a célt - többek között - a tervezett karbantartási idôtartam tartásával - lehet elérni.

A turbulens gazdasági környezet egyre inkább „éles helyzetekben" történô döntéshozatalra kényszeríti a vállalatok menedzsmentjét. Ebben a helyzetben az integrált kockázatmenedzsment alkalmazása a döntéshozókat a különbözó stratégiai dilemmák közötti helyes választásban segítheti.

Az alkalmazott kockázatmenedzsment egyik célja a hatékony kockázatkezelési tevékenység biztosítása. A bemutatott esettanulmánnyal kapcsolatban ez azt jelenti, hogy a karbantartási munka átfutási ideje egyre inkább közelít a projekttervben rögzített eredeti idótartamhoz. A kockázatoknak fontos jellemzójük, hogy azok akkor is hatnak, ha azokat nem ismerjük fel idôben, így a kockázatok váratlan bekövetkezése nagy 
meglepetést okozhat, ezért - felkészületlenség hiányában - az azok kezelésére adott válasz nem lesz elég hatékony. Szisztematikus kockázatfelméréssel azonban a potenciális kockázatokat idóben fel lehet ismerni, és így hatékony kockázatkezelést lehet megvalósítani. A bemutatott esettanulmányban ez azt jelenti, hogy a hatékony kockázatkezelés növeli az esélyét a karbantartás tervezett időpontban történő befejezésének.

A projektkockázat-menedzsmentnek az egyedi projektek megvalósításának kockázatértékelésén túl több projektkockázat-felmérés szempontjából történô együttes értékelése is feladata, ezért mindenképp érdemes lenne további kutatásokat végezni abban az irányban, hogy miként lehetne elősegíteni több projekt együttes kockázatmenedzsmentjének segítségével az adott szervezet stratégiai céljainak elérését.

\section{Lábjegyzet}

${ }^{1}$ A tanulmányban a pénzáramlás nettó jelenértékét kockázatmentes kamatlábbal számoltuk.

${ }^{2} \mathrm{Az}$ irány pozitív, ha egy változó értékének növekedése egy másik változó növekedését idézi elô, és negatív, amennyiben egy változó értékének csökkenése egy másik változó értékének növekedését okozza. Az intenzitás mértéke a korrelációs faktorral mérhető, amely -1 és +1 közötti értékeket vehet fel (Hunyadi et al., 1993).

${ }^{3}$ Relatív szórás: a szórás és a várható érték hányadosa.

${ }^{4}$ A független valószínúségi változó értékének változása változást idézhet elố a függő valószínúségi változó értékében.

${ }^{5}$ Ez akkor igaz, ha a nettó jelenértéket kockázatmentes kamatlábbal számoltuk.

${ }^{6}$ Pl. Oracle Crystal Ball, Palisade @ Risk, Szigma Integrisk

\section{Felhasznált irodalom}

Ai, J. - Brockett, P.L. - Cooper, W. - Golden, L. (2012): Enterprise Risk Management through Strategic Allocation of Capital. Journal of Risk \& Insurance, 79, 1: p. 29-56.

Anderson, R. - Frigo, M. (2012): What Should Directors Ask about Risk Management? Strategic Finance, 93, 10: p. 17-20.

AS/NZS 4360:2004, Risk Management 82004 by Standards Australia and Standards New Zeeland, subsequently replaced by AS/NZS ISO 31000, 2009

Balaton Sz. - Báthory B. - Daróczi M. - Fekete I. - Füle M. - Görög M. - Hollósi L. - Husti I. - Papp O. - Pethó M. - Szlávik J. - Tóth T. - Vígh T. (2005): Beruházási kézikönyv. Budapest: Múszaki Könyvkiadó: p. 94-96.

Bannerman, P.L. (2008): Risk and Risk Management in Software Projects: A Reassessment. The Journal of Systems and Software, 81 (12): p. 2118-2133.

Bartlett, J. (2004): Business \& Economics Project Risk Analysis and Management Guide. 2nd Edition. New York: APM Publishing Limited
Boda Gy. - Szlávik P. (2005): Kontrolling rendszerek. Budapest: KJK-KERSZÖV Jogi és Üzleti Kiadó Kft.: p. 93-100.

Boehm (2009): Computer Science, Volume 387: p. 1-19.

Brealey, R.A. - Myers, S.C. (1993): Modern vállalati pénzügyek. Volume II. Budapest: Panem Kiadó: p. 17-18.

Cerpa, N. - Verner, J.M. (2009): Why did Your Project Fail? Communications of ACM, 52 (12): p. 130-134.

Chapman, C. - Ward, S. (2003): Project Risk Management Processes, Techniques and Insight, $2^{\text {nd }}$ Edition. New York: John Wiley and Sons Inc.

Chow, T. - Cao, D.B. (2008): A Survey Study of Critical Success Factors in Agile Software Projects. Journal of Systems and Software, 81(6): p. 961-971.

Cleden, D. (2009): Managing Project Uncertainty. London: Gower Publishing Limited, England: p. 80-83.

Cooper, D.F. - Chapman, C.B. (1987): Risk Analysis for Large Projects: Models, Methods and Cases. New York: John Wiley and Sons Inc.

De Bakker, K. - Boonstra, A. - Wortmann, H. (2010): Does Risk Management Contribute to IT Project Success? A Meta-Analysis of Empirical Evidence. International Journal of Project Management, 28 (5): p. 493-503.

Eilon, S.C. - Fowkes, T.R. (1973): Sampling Procedure for Risk Simulation. Operational Research Quarterly, Vol. 24: p. 241-252.

Evans, M. et al. (1993): Statistical Distributions. Second Edition. New York: John Wiley \& Sons Inc.

Farkas Sz. - Szabó J. (1998): Kockázatmenedzsment. Budapest: PMS 2000 Mérnöki Társaság: p. 18-22.

Fekete J. Gy. (2011): Környezeti stratégiák. Veszprém: Pannon Egyetem - Környezetmérnöki Intézet 14. fejezet: Stratégia és gazdaságosság

Frigo, M. - Anderson, R. (2011): Strategic Risk Management: A Foundation for Improving Enterprise Risk Management and Governance. Journal of Corporate Accounting \& Finance (Wiley), 22, 3: p. 81-88.

Görög M. (2008): Projektvezetés. Budapest: Aula Kiadó: p. $137-150$.

Grey, S. (1995): Practical Risk Assessment for Project Management. New York: John Wiley \& Sons Ltd.: p. 81-97.

Haris, E. (2009): Strategic Project Risk Appraisal and Management. London: Gover Publishing Ltd.: p. 28-29.

Hartman, J. - Ashari, R.A. (2002): Project Management in the Information Systems and Information Technologies Industries, Project Management Journal 3383 5-15.

Herz, D.B. (1964): Risk Analysis in Capital Investment. Harvard Business Review, 42 January-February: p. 95-106.

Hillson, D. (2002): Extending the Risk Process to Manage Opportunities. International Journal of Project Management, 208(3): p. 235-240.

Hopkin, P. (2012): Fundamentals of Risk Management: Understanding Evaluating and Implementing Effective Risk Management. ${ }^{\text {nd }}$ Edition. 18. The Institute of Risk Management 
Hunyadi L. - Mundruczó Gy. - Vita L. (1993): Statisztika II. Budapest: Aula Kiadó

ISO 31000 (2009): Risk Management - Principles and Guidelines by the International Organization for Standardization

Jorion, P. (1997): Value at Risk The New Brenchmark for Controlling Derivatives Risk. Maidenhead: The McGraw-Hill Companies Inc.

Kaplan, R.S. - Norton, D.P. (2000): The Strategy-Focused Organization. How Balanced Scorecard Companies Thrive in the New Business Environment. Boston, MA: Harvard Business Scholl Press

Lind, M.R. - Culler, E. (2011): Information Project Performance: The Impact of Critical Success Factors. International Journal of Information Technology Project Management, 2(4): p. 14-25.

Loosemore, M. - Raftery, J. - Reily, C., Higgon, D. (2005): Risk Management in Projects, Second Edition. London: Taylor \& Francis: p. 43-65.

Machowiak, W. (2012): Risk Management - Unappreciated Instrument of Supply Chain Management Strategy. Logforum, 8, 4: p. 277-285.

Nakatsu, R.T. - Iacovou C.L. (2009): A Comparative Study of Important Risk Factors Involved in Offshore and Domestic Outstanding of Software Development Projects. A Two- Panel Delphi Study Information \& Management, 46(1): p. 57-68.
Ohtaka, H. - Fukazawa, Y. (2010): Managing Risk Symptom: A Method to Identify Major Risks of Serious Problem Project in SI Environment using Cyclic Causal Model. Project Management Journal, 41 81: p. 51-60.

Papp O. (2002): Projektmenedzsment a gyakorlatban. Budapest: LSI Oktatóközpont: p. 198- 213.

PMBOK (2008): A Guide to the Project Management Body of Knowledge, Fourth Edition. Project Management Institute

Sári V. (2011): Kockázatmenedzsment és kockázatkontrolling a vállalati gyakorlatban. http: //hdl.handle. net $/ 2437 / 103411$

Summer, M. (2000): Risk Factors in Enterprise-wide/ERP Projects. Journal of Information Technology, 15: p. 317-327.

Tatai T. - Pataki L. (2008): Kockázatelemzés, kockázatmérséklés cselekvési tervek. Budapest: Raabe Kiadó: p. 28-32.

Watchorn, E. (2007): Applying a Structured Approach to Operational Risk Scenario Analysis in Australia. Australian Prudential Regulation Authority (APRA). Working Paper

Weitzner, D. - Darroch, J. (2010): The Limits of Strategic Rationality: Ethics, Enterprise Risk Management, and Governance. Journal of Business Ethics, 92, 3: p. 361372. 